\title{
THE ORIGINS OF THE BRITISH RED CROSS SOCIETY AND THE POLITICS AND PRACTICES OF RELIEF IN WAR, 1870-1906
}

\author{
Rebecca Gill \\ History Department, University of Huddersfield, UK \\ R.gill@hud.ac.uk
}

Received: 3 December 2013; Accepted: 20 February 2014.

Citation /Cómo citar este artículo: Gill, Rebecca (2014), "The origins of the British Red Cross Society and the politics and practices of relief in war, 1870-1906", Asclepio 66 (1): p029, doi: http://dx.doi.org/10.3989/asclepio.2014.03

\begin{abstract}
This article traces the history of the British National Society for Aid to the Sick and Wounded in War (NAS), and its interventions in Continental and colonial wars of the late-nineteenth century. The NAS was founded on the outbreak of the FrancoPrussian War in August 1870. It went on to become one of the most important founding members of the British Red Cross Society (BRCS) when it was established in 1905. The aim of the article is to uncover the particular anxieties and aspirations that contributed to the foundation of the NAS. It demonstrates how these concerns -many of them related to the relative state of the British militaryinformed its subsequent practices and its relationship with the International Committee of the Red Cross. In tracing its emergence as a paramilitary corps adept at rapid-response emergency medicine, this article uncovers the rivalry that characterized attempts within the NAS and BRCS to lay claim to the "true spirit" of voluntary aid in war -a rivalry which eventually informed British insistence on a revision to the Geneva Convention in 1906.
\end{abstract}

KEY WORDS: relief work; militarism; Franco-Prussian War; British Red Cross Society; Geneva Convention.

\section{LOS ORÍGENES DE LA SOCIEDAD DE LA CRUZ ROJA BRITÁNICA Y LAS POLÍTICAS Y PRÁCTICAS DEL SOCORRO EN GUERRA (1870-1906)}

RESUMEN: Este artículo rastrea la historia de la British National Society for Aid to the Sick and Wounded in War (NAS) y sus intervenciones en las guerras europeas y coloniales de finales del siglo XIX. La NAS se fundó con el estallido de la Guerra FrancoPrusiana en agosto de 1870. Acabó convirtiéndose en uno de los miembros fundadores más importantes de la Sociedad de la Cruz Roja Británica (BRCS) cuando se estableció en 1905. El propósito del artículo es mostrar las peculiares inquietudes y aspiraciones que contribuyeron a la fundación de la NAS. Demuestra cómo estas preocupaciones -muchas de ellas asociadas al status de los militares británicos- condicionaron sus prácticas subsiguientes y sus relaciones con el Comité Internacional de la Cruz Roja. Al rastrear el surgimiento de la NAS como un cuerpo paramilitar experto en urgencias médicas de respuesta rápida, este artículo pone de manifiesto la rivalidad que caracterizó los intentos dentro de la NAS y de la BRCS por atribuirse el "verdadero espíritu" de la ayuda voluntaria en la guerra -una rivalidad que propició la insistencia británica en revisar la Convención de Ginebra en 1906.

PALABRAS CLAVE: labores de Socorro; militarismo; Guerra Franco-Prusiana; Sociedad de la Cruz Roja Británica; Convención de Ginebra.

Copyright: (c) 2014 CSIC. This is an open-access article distributed under the terms of the Creative Commons Attribution-Non Commercial (by-nc) Spain 3.0 License. 
The International Committee of the Red Cross [ICRC], the self-appointed guardians of the Geneva Convention, are marking their 150th anniversary with historical reflection upon a venerable institution. ${ }^{1}$ These institutional histories do not evade controversy or shy away from the challenging assertion that today their core values are being overshadowed by a bureaucratic imperative (Palmieri 2012). But they do describe an organisation with a taken-for granted status and long-standing influence. The irritated description by one nineteenth-century British observer of an "irresponsible Committee of Swiss gentlemen" who "perform no function that is of real importance" may come, therefore, as something of a surprise. ${ }^{2}$ Further probing reveals the extent to which in the latenineteenth and early-twentieth centuries the British medico-military establishment ensured that the ICRC was kept marginal, and on occasion made to bow to, its concerns. For in Britain, as elsewhere, the development of organisations and regulations for the protection of the sick and wounded in war was as much the manifestation of anxiety over the relative strength of the British military, as it was the embodiment and gradual popularisation of a shared humanitarian ideal. Allusions to "neutrality", "voluntarism" and "humanity" -far from being foundational or stable- operated within a politics of relief that enmeshed articulations of British foreign policy and imperial mission with shifts in the purpose of voluntary aid and the changing nature of the state itself. This article traces the early history of the British voluntary aid movement, investigating how these considerations shaped the practices, technologies, and protocols that came to be associated with the role of the Red Cross in war. It also demonstrates how these priorities determined the relationship between the British National Society for Aid to the Sick and Wounded in War (forerunner of the British Red Cross Society) and the ICRC, and how they eventually informed British insistence on a revision to the Geneva Convention in 1906. Such an approach raises questions about how we write the history of the Red Cross movement and the history of humanitarianism more generally.

This, then, is an example of organisational history -but one written through reference to a broad web of affiliation and practice. In this way, this article revises a more traditional tendency to write the history of the Red Cross movement through the internal politics of the ICRC to the exclusion of the history and practice of the aid worker, or to approach the history of humanitarianism as an exercise in the history of ideas or international relations. ${ }^{3}$ Historians have emphasized a revolution in conscience, pity, ethics and "affective relationships" in this period, but have tended to overlook the decisions of committee members, the ethical dilemmas of aid workers on the ground, and the discordant ways in which individuals appropriated the vocabulary of empathy and rights. ${ }^{4}$ Thus while a history of Evangelical and Enlightenment ideas of rights and duties has merit in helping to trace reconfigurations in the meaning of "humanity", the relationship of ethics to practice and ideals to organisational form tend to be assumed rather than described. ${ }^{5}$ Often it is more interesting to consider, for example, how relief workers in the Ottoman Empire appropriated the legacy of the anti-slavery crusade than consider them the direct heirs of shared compassion and idealistic conviction. By the same token, other than mention Henri Dunant and other "founding fathers" there is a tendency to write peopleless history, sidestepping the logistics experts, pioneering medics, innovative nurses, adventurers, committee stalwarts and assorted cranks who administered relief societies and ran their hospitals. Yet personality mattered, as did the family dynasties and married couples who in Britain tended to keep this activity in-house and proudly amateur.

A recent surge of interest within International Relations scholarship has seen "humanitarian intervention" depicted as an ideal against which various actions are tested (Trim, Simms, 2011, pp. 4-5.). The focus has been diplomatic and military intervention undertaken, sometimes coercively, by states in collaboration with other states. The point has been to establish that such action has always been a feature of international relations rather than a (recent) anomaly and that state sovereignty has never been considered absolute (Trim, Simms, 2011, p. 5). But in excluding "non-state" actors from this analysis, the role of voluntary organisations in priming political actors and engaging in unofficial diplomacy has been ignored, and the multifaceted nature of this intervention is overlooked. As Stéphanie Prévost notes, "humanitarian diplomacy" took place in the nineteenth century -as today- by non-state actors engaged in securing access to populations in distress and often in close collaboration with the consular services. ${ }^{6}$ She points to the work of Philippe Régnier in elaborating the ways in which, in disaster or conflict situations, such diplomacy takes place on the ground, often in pragmatic fashion (Régnier, 2011, p. 1221). Moreover, in the nineteenth century, it was quite common for relief workers to consciously pursue the foreign policy aims of their party and country if they considered the stabilization or liberation of a suffering population to be a moral cause in the British national interest.

This means that we cannot extricate the history of state intervention from the range of actors who undertook interventions abroad in the name of humanity -and without addressing the very varied motivation and sense of moral purpose which they invoked. On the one hand, there is too much of a desire to disentangle the state from the "NGO": indeed this terminology, and this concern for organisational "in- 
dependence", would seem overly to reflect a presentday preoccupation within the sector (Trim, Simms, 2011, p. 20; Rodogno, 2011, p. 3). Indeed, for much of the late nineteenth and early twentieth centuries, relief workers inhabited overlapping circles within politics, the War Office, consular services, charities, journalism and academia, such that many could be said to be part of the governing establishment. Very rarely did the "career" relief worker exist; more commonly, those dispensing aid in a foreign conflict were seconded from the army or were men of business, nurses or charity workers, consulate staff, or surgeons on leave from a teaching hospital. Far from stable sectors, the state and voluntary organisations intersected and were themselves in flux: the Red Cross movement in Britain was at once a prime example of the "civilianising" of the army in this period, and a militarisation of civil society (Summers, 2000, chap. V). On the other hand, the allusion to Régnier's notion of the contingencies of "humanitarian diplomacy" in the field directs our attention to how this establishment operated in practice and to the ethics of action, and thus to why a focus on the ideals of the ICRC and Geneva Convention will only ever reveal part of the story. It is telling that those dispensing aid for the British National Society for Aid to the Sick and Wounded in War were as likely to declare their neutrality in foreign conflict a facet of their English chivalry, as they were to make reference to the articles of the Geneva Convention.

\section{THE FOUNDATION OF THE BRITISH NATIONAL SOCIE- TY FOR AID TO THE SICK AND WOUNDED IN WAR}

The British National Society for Aid to the Sick and Wounded in War (NAS, hereafter) had its first public meeting on 2 August 1870 not, as might be expected, in anticipation of fearful casualties from the FrancoPrussian War, but because the moment was opportune to proclaim the "cause of humanity" and to stir fears for the welfare of British troops in a similar conflict. ${ }^{7}$ Lt.-Col. Robert Loyd Lindsey V.C., hero of the Crimea (and very-nearly a casualty of its hospitals) was elected Chair. Many of those who met in Willis' Rooms on Piccadilly that day had for several years been attempting to found a national society for the aid of the wounded in war but had failed to arouse the necessary enthusiasm. Now, with the prospect of an ascendant Prussia, and a question mark over Britain's fighting strength, observers of military affairs found these matters suddenly pressing. Loyd Lindsay's father-inlaw, the wealthy banker Lord Overstone, grumbled that "[t]he state of our Army ... is ridiculous", and took up a place on the Executive Committee. ${ }^{8}$ Despairing of Gladstone's retrenchment at the War Office, Overstone trusted that his country would "learn a solemn lesson from the works of Bismarck and of Moltke" and attend to military capacity. ${ }^{9}$ The War Office, reluctant to sponsor a voluntary aid corps officially, nevertheless wished to observe Continental developments at a distance; and, with the launch of the NAS, now had the means to do so.

The spur for the meeting was a letter to The Times from a Capt. Burgess of the Order of St John in England, urging consideration that "Every country in Europe, except England, has its "Société de Secours aux Blessés et Malades Militaires". Now is our opportunity to form a strong British 'Society of Help for the Sick and Wounded."'10 "It should be well understood", he clarified a few days later, "that our object is not to interfere in any way with the military medical staff, but to temporarily tend the wounded until the hardworked surgeons can look to them - to gather men from the battlefield instead of leaving them to be there, in horrible pain and thirst, unsheltered and helpless, for hours or days. We want to help the surgeons, not to hamper them."11 The principle of first aid on the battlefield was thus put forth: and it would be precisely in its emergency care and transport services that the NAS, in an uneasy collaboration with the Order of St John, would find its niche.

The Times returned to the theme of English deficiencies a week later when it reviewed Help for the Sick and Wounded, a translation by John Furley of $L a$ Guerre et la Charité, a guide to the organisation of voluntary aid by Gustave Moynier and Louis Appia of the ICRC. Furley had intended to "call public attention to the subject", and The Times duly pressed the virtue of "private individuals, as members of the great brotherhood of civilized humanity, [doing] their best to remedy this insufficiency". ${ }^{12}$ They reported how, "during peace, such relief societies ought to find for themselves employment in works of humanity more or less analogous to their duties in times of war" in "such disasters as railway accidents, mining accidents, and accidents by floods". ${ }^{13}$ Bound with Furley's translation were two further pieces, the one a lecture to the Royal United Services Institution by Deputy-Inspector-General of Hospitals Sir Thomas Longmore on the Geneva Congresses, the other a report on the care of the sick and wounded in war by Captain Brackenbury of the Royal Artillery. Burgess, Furley, Longmore and Brackenbury, all members of the recently revived Order of St John, would soon become the pivot of exchange between the NAS, ICRC and reformist elements at the War Office. ${ }^{14}$ From the outset, they shared an assumption that greater proficiency in emergency care and exposure to innovations in medical practice abroad would inspire public interest in the question of soldiers' welfare and provide a necessary spur to the modernization of the army medical services at home. It was for this reason that Florence Nightingale, though worried that Genevan initiatives might "render war more easy", was nevertheless quick to 
lend her support to the fledging NAS and stamp her mark upon it. ${ }^{15}$ As she opined to her ally Sir Thomas Longmore,

I am more than ever convinced that Governments should be made responsible for their own Sick and Wounded - that they should not decline Volunteer, private, benevolent effort but that, exactly in the measure that this is incorporated in, not substituted for Government organisations (for sick and wounded). ${ }^{16}$

Sir Thomas Longmore, the first professor of military surgery at Netley, and the pre-eminent military surgeon of his day, had for several years been corresponding with Nightingale on the topic. ${ }^{17} \mathrm{He}$ had represented Britain at the Geneva Congress at which the 1864 Geneva Convention had been negotiated, and was mindful of the lessons of the earlier medicomilitary disaster in the Crimea. Indeed, it was Nightingale's War Office memorandum on the arrangements of the army medical service for future conflict that he had been instructed to uphold in Geneva. His brief was to consent to international protocols only so far as they complemented existing British military provision. Thus a proposal to create teams of independent medical volunteers, first discussed at a preliminary Genevan Congress of 1863 (and a central proposal of Henri Dunant's A Memoir of Solferino) was to be strictly opposed. From Geneva, Longmore had written to London that, "there is no intention of discussing at this Congress the question of Volunteer assistance or of any modifications of the ... management of the existing military hospital system of any country." ${ }^{18}$ Nightingale could be reassured, that, on paper at least, no unregulated or amateur volunteer would dilute the government's proper responsibility for the wounded or divest trained nurses of a new vocation in war. An invitation from Capt. Burgess to address the Royal United Services Institution in 1866 provided Longmore with opportunity to publicize the protocols of the new Geneva Convention in Britain and to stress their confines:

I have dwelt upon the special purpose of the Congress, because it was supposed by some persons that the question of independent volunteer attendants, which had been discussed, as I have already mentioned, in the former assembly of 1863, was again to be opened and discussed in the Congress of 1864 . This erroneous supposition led to the Congress being regarded with suspicion, and even with positive disapprobation, by some who would doubtless have regarded it very differently had no such views been entertained by them. ${ }^{19}$

Membership of the Order of St John had brought Longmore into the milieu of a group of men and women eager to appropriate the Hospitaller tradition of the original medieval Knights of St John. The current Order of St John of Anglia was established in the 1860 s, its members combining a Victorian love of chivalry with a desire to perform "good works". ${ }^{20}$ An earlier attempt at nursing the sick poor had foundered for lack of money; but they had soon taken up a new crusade: the care of those wounded in war and industrial accident. Unfortunately, however, their views on the role of the volunteer in war brought them into almost immediate conflict with Loyd Lindsay and the wealthy patrician amateurs of his extended and influential circle. The dispute over the meaning and purpose of voluntary aid in war would divide the Red Cross movement in Britain for a generation. The creation of an auxiliary voluntary medical corps was anathema to those who valued the independence and outspokenness that came with organisational autonomy. For Loyd Lindsay, it was precisely this independent spirit of "voluntarism" which would ensure public donations, and draw attention to the needs of those the army medical services did not deem a priority. Had a NAS existed at the time of the Crimea, "much suffering would have been averted and many lives saved". As Loyd Lindsay's wife and biographer explained,

[w] hat he saw and experienced during that campaign impressed itself deeply on his mind; he realised that however well organised an Army Medical Service may be, it never has been, and never will be, able to cope adequately with the sudden emergencies of war on a large scale, and he held that voluntary organisations, unimpeded by official restrictions, are alone capable of giving auxiliary relief and of providing extra comforts and luxuries with the requisite promptitude and rapidity (Lindsay, 1907, p. 172).

\section{FIRST AID IN WAR: THE DEVELOPMENT OF A SPECIALISM}

From his vantage point at Netley, the model military hospital constructed after the Crimean War, Longmore was able to survey the growth of military surgery and of a whole slew of inventions and appliances designed to aid rapid treatment and recovery. In the treatment of gunshot wounds he became an authority. Those of his papers preserved in the Wellcome Library in London reveal the development of a transnational field of expertise in the retrieval, conveyance and accommodation of the sick and wounded, covering everything from the use of antisepsis to the deployment of hospital trains. As early as 1869, Longmore and Furley were corresponding on the subject of "flying hospitals", designed to replace the stationary hospital of the Crimean War with temporary hospital tents. ${ }^{21}$ Medical volunteers were to act as a flying corps occupied in bearing stretchers, driving ambulance wagons, and staffing temporary hospitals. The merit of these proposals were to be borne out by the desultory experience of the French wounded in 1870 , and bolstered by the far superior example of Prussian sanitary and medical arrangements. 
Though prevented by illness from joining the NAS on its first mission to France, Longmore followed its work through the writings and communications of colleagues who had either volunteered in a private capacity, such as John Furley of the Order of St John, or had been seconded from the army medical services. The Franco-Prussian war, with an already insufficient French army medical corps stretched to capacity, provided the British volunteers with a welcome degree of latitude to survey and to experiment. "We ... saw and did much good surgical work, for which there was ample material and constant opportunity", Henry Rundle observed from his post as surgeon with the Prussian forces. ${ }^{22}$ The chance was taken to trial Lister's antiseptic methods in war (and to note the difficulty of transporting the necessary equipment) and to experiment with the subcutaneous administration of morphine for bullet wounds. Creswell Hewett noted "the experience which we ought to gain for our own use, in the management of our War Services". ${ }^{23}$ This lesson was not lost on Ernest Hart, the editor of the British Journal of Medicine, who commissioned pieces by British surgeons at work in the war, and volunteered his own services for the distribution of material in France (Rundle, n.d., p. 34). His publication of "articles from the front" by William MacCormac of St Thomas' Hospital in London revealed the curiosity of a young surgeon to "see what military surgery was like" (MacCormac, 1871, p. 1). These remarkable articles (subsequently published in book form) interspersed humane reflections on the suffering of war with picturesque jottings on the French countryside. They also enumerated a series of case histories with clear pedagogical intent. Within the turn of a page one could learn how,

The stillness during the ride that bright sunny autumn afternoon was most oppressive, and the beautiful sky overhead formed a contrast to the earth beneath, outraged by human passion and violence, that afforded food for reflection ...

Today I used the trephine in a case of depressed fracture with compression of the brain from effusion, of which I may give a few particulars (MacCormac, 1871, p.p. 62-63).

Sandford Moore, assistant-surgeon to the 4th Royal Irish Dragoon Guards, concurred that "rare opportunities were thus presented" for observation of foreign medical arrangements, especially "the working of the wheeled transport, British and Prussian, the former of which had not been previously tried in European warfare" (Moore, 1872, p. 6). This became the subject of a thorough survey. The Prussian ambulance wagons were described in sufficient detail that a replica could be constructed, down to the optimum radius of the wheel and the requisite elasticity of the springs. Sandford Moore also observed the dispatch to the seat of war in October 1870 of the
Woolwich Ambulance, run in the name of the NAS, but operating as an experiment in British ambulance provision under the direct control of the DeputyInspector-General, and provided at cost price from British military stores. The Woolwich "field" hospital (with 12 hospital marquees, 8 ambulance wagons, 27 members of the army hospital corps and provisions and bedding for 200 patients) was the first of its kind to be used by a British military staff. Its departure offered opportunity for a rehearsal.

During the Franco-Prussian War, the NAS oversaw complete ambulance units such as the Woolwich, as well as individuals attached to the French and German medical services. In total, the NAS engaged 110 people to distribute aid and provide medical assistance, comprising 62 surgeons, 16 nurses and 32 agents responsible for running depots in France. ${ }^{24}$ NAS personnel were expected to telegraph the Society at home of their requests for stores and equipment, and the NAS in turn to equip a series of depots in north-eastern France. The ad hoc nature of NAS services, limited by duplications and inefficiency, was eventually replaced with a systematic operation. Its success was testimony to the logistical skill of Capt. Henry Brackenbury, who had been seconded from the army for the purpose. He started by founding the depot at Arlon, before laying down supply lines between hospitals in the district of Metz and the Ardennes. "The great questions now are depôts and transport. To have the stores at hand and the means of conveying them where wanted are the two first necessities of the moment.". ${ }^{25}$ Under Brackenbury's guidance, the NAS quickly assumed the bearing of a military operation and he soon took to styling himself the "commander-in-chief, from whom [relief workers] get systematic instructions." ${ }^{26}$ Brackenbury, a man of great perspicacity, was Professor of Military History at Woolwich, and a sometime war-correspondent for the Standard. His experience and his considered views on the role of the Red Cross in war, some of which he voiced in print, would make him a valuable link between the Order of St John and the War Office modernisers associated with Sir Garnet Wolseley.

Like her associate Sir Thomas Longmore, Florence Nightingale's health prevented direct observation of British relief work in France, though she too had a hand in the arrangements described by her correspondents. Her priority was to prove the efficacy of the female nurse in war. Through the presence of her brother-in-law Sir Harry Verney on the Committee of the NAS, and her sister, Emily, on the Women's Committee, Nightingale was able to influence the vetting process. As she instructed them, "I hope to learn what the Committee think on all these points, and propose to do, before they take any step about Volunteer Nurses". 27 "Col Lindsay is quite right about Volunteer Nurs- 
es", she advised, "They may make themselves a terrible nuisance (or even an immoral nuisance) unless under certain rules, under proper authority and round a trained nucleus." ${ }^{28}$ Nonetheless, if Loyd Lindsay was to be commended for his appreciation of the trained nurse, he was to be censured for his amateurism: "I am terrified at what you say that Col. Lindsay is "perplexed what to do and how to begin". Have they really got no further than this? It makes one despair of Englishmen." ${ }^{29}$ This refrain would become a familiar one. Nightingale could, however, take satisfaction that the trained nurse was proving her worth. Sandford Moore spoke for many: "Women are better adapted, both physically and morally, for the charge of the sick than men. They should, however, in order advantageously to fulfil their mission of good, be adequately trained, and then they become invaluable" (Moore, 1872, p. 83). Nightingale was further reassured by the letters from the front of her protégé Florence Lees and it was to Lees that the task fell of summing up the Nightingale position in an appendix to the NAS's report. ${ }^{30} \mathrm{De}-$ crying the sight of "English ladies rushing wildly over the country, sleeping sometimes in the open field, and writing thrilling letters home of their work and hardships", Lees proposed the appointment, in future conflicts, of a "Director-General of the Medical Staff with all surgeons, dressers, lay agents, and commissariat arrangements at his absolute control (he himself being under ...the Society)". He would be assisted by,

some gentlewoman appointed as SuperintendentGeneral of Nurses, having the direction of all superintendents, sisters, and nurses who were on the staff of the Society, to whom all complaints concerning such should be made, and who should be responsible to the Society for the right use of the powers entrusted to her. $^{31}$

\section{THE “TRUE” SPIRIT OF VOLUNTARY AID IN WAR}

For Nightingale, and for the Order of St John, the lessons of the Franco-Prussian War confirmed their existing views on the need for an on-demand auxiliary medical service staffed by trained volunteers and

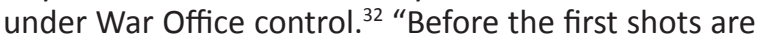
fired", Brackenbury suggested,

a chief representative should be sent to each army in the field. He should organise on the spot small moveable ambulances, each consisting of say two or three surgeons; a few surgical or medical stores; and a light conveyance. ... It is most important that this organisation should be formed before the hostilities commence. It was most unfortunate that circumstances prevented our Society from organising its aid in the commencement of this campaign. ${ }^{33}$

Longmore was adamant that the NAS in France did not have a legitimate status: that it had claimed for itself the immunity of a neutral voluntary organisation when no such position existed under the 1864 Geneva Convention. As he was at pains to make clear to the Royal United Services Institution:

The Geneva Convention is simply a Treaty entered into by certain Governments with regard to the manner in which the sick and wounded of their armies, the staff employed in ministering them, and the military hospitals and hospital materiel, are to be respectively dealt with in case of two or more of those Governments waging war with each other. ... The treaty nowhere contains reference to the neutralisation of any one not forming part of the Staff originally employed in the service of the ambulances and hospitals of the belligerents; there are no stipulations in it regarding private persons (Longmore 1866, p. 7).

Yet the other lesson of the Franco-Prussian War was that suffering and need, especially if measured by civilian standards of hygiene and comfort, would almost always leave room for amateur and freelance assistance, especially when bankrolled by wealthy patrons. And so it proved that the ideal of prepared, trained and disciplined voluntary aid on the battlefield, now the defining principle of the Order of St John's work in this regard, could never fully be met, not least because the Order had only meagre financial resources. The interfering "do-gooder" and the "lady amateur" rapidly became the Order of St John's bêtes noires: John Furley complained of "spasmodic fussiness and philanthropic insanity" and this became something of a mantra (Furley, 1885, p. 879). Yet for NAS Chair Loyd Lindsay, things stood rather differently. The NAS had received a windfall of cash donations during the Franco-Prussian War, far exceeding its expectations. In a letter, Lord Overstone described how, "the contributions pour in so rapidly and to so large an amount that it has been found necessary to enlarge the sphere of operation - and to undertake duties which were not at first in contemplation." ${ }^{34}$ At the end of the war, a large amount of the $f 297,000$ bestowed on the NAS remained unspent. ${ }^{35}$ This gave the organisation financial independence; indeed, it did not have to make a direct appeal for funds until the Boer War of 18991902. For those at the Order of St John, this surplus seemed ripe for funding a peacetime ambulance corps. Loyd Lindsay demurred. "[T]he public mind ... was not likely to respond to any elaborate organisation or preparation in time of peace," and "what was given was spontaneously given", he cautioned. For, he argued, "one of the great advantages of voluntary societies is, that their agents can work untrammelled by military regulation". ${ }^{36}$

At the close of the Franco-Prussian War, disputes over the spirit and purpose of voluntary aid resulted in the resignation of several members of the Order of St John from the NAS and the foundation of their own "Ambulance Department". Furley and his circle channelled their frustration into a new campaign: the 
winning over of public and political opinion to the Order's scheme of ambulance work. As Col. Brackenbury recounted,

After mature consideration, it seemed to me I had a duty beyond that which I owed the Society -a duty to the people at large- which was to do what I could by bringing external pressure to bear to induce the [NAS] Council to take up this as their most important avocation. In order to criticise their position from an exterior point of view, I resigned my seat on the Council and I wrote and advocated in the Press that they should take up a work of this nature, which has since been taken up by the Order of St John. ${ }^{37}$

With considerable entrepreneurial spirit, John Furley took up the campaign. ${ }^{38}$ His observations of the mechanics of ambulance work were turned to account on his return to England through the design of wheeled stretchers and first-aid accruements. He was consistently attentive to the comfort of the injured and their ease of transportation: telescopic handles for stretchers that could be then loaded directly into ambulance wagons, electric lights for ambulances to aid night-time search parties, and India-rubber tyres to minimise uncomfortable jolts. These designs were then patented and put into production by Messrs. Marshall Bros., a firm of coachbuilders in Ashford, his hometown. These became known as Ashford Litters (ambulance wagons) and Furley Pattern Stretchers and could be purchased through the St John "Ambulance Department", of which Furley was store manager. ${ }^{39}$ In the year 1895, for instance, 33 Ashford Litters and 359 Furley Stretchers were sold to St John's Divisions and first-aid stations in factories, pit heads and railway stations up and down the country (St John Ambulance Association, 1895, p. 17).

Furley travelled widely to promote the advantages of trained St John Ambulance personnel and to demonstrate the virtue of his designs. He secured contracts to supply the London County Council asylum board, the metropolitan police, and numerous hospitals; attended meetings of local social science conventions; and awarded medals to winning teams of railway men at stretcher-bearing competitions. For Furley, it seems, humanitarian gestures had diffuse recompense. In 1878, the St John Ambulance Association was launched and the Army Medical Department undertook the significant step of guaranteeing the Order all necessary materiel in event of a British war, provided the Order supply trained men and nursing staff (Order of St John, 1878, p. 19). By the end of that year, 1,100 men and women had attended a St John first-aid class, and regional branches continued to spring up. A year later, approximately 3,000 people had completed the course in London alone (Summers, 2000, p. 142).

\section{THE POLITICS OF RELIEF}

In 1889 the St John Ambulance Association published its Reports of First and Second "Crusades" in the Northern Counties of Durham and Northumberland (St John Ambulance Association, 1889). These were part of a wider campaign to establish first-aid centres in the regions and to thwart Loyd Lindsay and other "unbelievers" on the NAS Council. By now, this internal politics of relief had become entangled with party politics and broader concerns over Britain's role in foreign affairs. Palmieri notes that, in the nineteenth and early twentieth centuries, the ICRC did not concern itself with wars other than between European nation states (Palmieri, 2012, p. 7). The same was not true of those wearing the Red Cross armband and proffering relief on behalf of national societies. Britain's abstention from the Franco-Prussian War had conferred upon British relief workers the neutrality of their nationality, and had deferred the question of loyalty in the event of a British war. But events in the Balkans, and British Army involvement in the "scramble for Africa", soon altered the status and purpose of voluntary aid work, and brought it increasingly to the War Office's attention.

In 1876, on outbreak of war between Serbia and Turkey, members of the Order of St John met at the house of their Grand Prior Sir Edmund Lechmere to establish an Eastern War Sick and Wounded Relief Fund. After a public meeting at Willis' Rooms, it was decided to amalgamate with the NAS to form a joint Committee for "Turko-Servian Relief" underwritten with a $£ 20,000$ grant from the NAS. This organisation took over the surgeons and stores already dispatched by the Eastern War Sick and Wounded Relief Fund. Disagreements arose from the start. Loyd Lindsay's insistence on opening a stationary hospital in Belgrade seemed, to members of the Order, to ignore the lessons of the Franco-Prussian War. Having, it reported, "scarcely any voice" on the Committee, the Order's advocacy of flying hospitals was disregarded. "[D]effects in the organization, and even in the plan pursued, in administering the relief of the wounded," were duly criticised (Order of St John, 1877, p. 11). Members of the Order were rankled further by Loyd Lindsay's vocal denunciation of the Serbian rebellion, which he blamed on Russian intrigue, during his visit to the NAS's British hospital in Belgrade. Loyd Lindsay was a Tory MP in the Disraeli government. Such arguments were in keeping with the Prime Minister's unwillingness to support insurgents in the region for fear of antagonising and further weakening Britain's Ottoman ally. In this context, the distribution of NAS supplies by consular staff and their wives in Constantinople, Serbia and Albania operated as a form of "humanitarian diplomacy". ${ }^{40}$ For those associated with the Order, Loyd Lindsay's combination of po- 
litical propaganda and relief work was indefensible (Pearson \& MacLaughlin, 1877, p. 141). To Humphrey Sandwith, one of the original surgeons sent out by the Order, Loyd Lindsay was guilty of indulging, "Turkish proclivities at the expense of a charitable society." ${ }^{41}$ Archibald Forbes of the Daily News insinuated that Loyd Lindsay was spying on behalf of the Turks. The reality, it seems, was that Loyd Lindsay was documenting his observations of military arrangements and sending them to Disraeli. He even offered his services as a regional expert to the British delegation at the subsequent Peace Conference in Constantinople. ${ }^{42}$

Furley, with experience of aiding the wounded in the Paris Commune and of both sides in the Carlist War, was emphatic about the need for neutrality. ${ }^{43}$ But it is quite possible too that his anger over Loyd Lindsay's Balkan interventions was piqued by political sympathy. Certainly, the publications of many of those associated with the Order who dispensed relief in the region expressed their support for the Slav cause. Humphrey Sandwith condemned Turkish "barbarity" in letters he sent for publication in the British press, and was to later denounce the Turkish massacre of Bulgarians and accompanying "slave raids" in his pamphlet England's position with regard to Turkey and the Bulgarian Atrocities (Sandwith, n.d., p. 7). Paulina Irby, who had contributed funds to launch the original Eastern War Sick and Wounded Relief Fund, had previously devoted herself to work on behalf of Christian refugees in the region and made no secret of her support for Slav nationalism. ${ }^{44}$ Meanwhile Lady of the Order Viscountess Strangford opened her own Bulgarian Peasants Relief Fund, determined that "every piaster that I give away will pass from me into Bulgarian hands". ${ }^{45}$ Aid to Christians living in the Ottoman lands carried a symbolic charge for a body eager to appropriate the medieval Hospitaller tradition. Strangford had herself received the order of the Holy Sepulchre from the patriarch of Jerusalem to mark her ancestors' involvement in the crusades. ${ }^{46}$ Two years before the "Bulgarian atrocities", she had offered to re-establish the Order's presence in the Holy Land with a grant for a hospital in Damascus (Order of St John, 1874, p. $6)$. Though this venture never bore fruit, by the early 1880s, the Order had succeeded in founding an eyehospital in Jerusalem (Lechmere, 1883). With Disraeli attempting to avoid war with Russia through a precarious diplomatic balance-of-power, Henry Brackenbury was astute to the political consequences of this rush of ad hoc voluntary aid. Would it be unwarranted, he asked, in times of insurgency, if one of the belligerents "promptly inflicted summary justice upon these agents for aiding and abetting rebellion."? ${ }^{47}$ Once again, he counselled the need for voluntary aid to be regulated and brought under the control of the War Office. In the event, Britain remained neutral, though jingoism and the fear of a war in the Balkans gave added impetus to the newly-founded St John Ambulance Association (Summers, 2000, p. 141). But it would take a British war for these questions to stimulate War Office action.

In 1884 the NAS undertook its first foray in support of the British Army. To accompany General Wolseley in his daring mission to rescue General Gordon at Khartoum, the NAS had commissioned a speciallydesigned steamer to withstand the shallow waters of the River Nile. With few men lost to injury in this campaign, NAS funds, after the salaries of staff had been deducted, were spent mostly on oranges and tobacco for the comfort of the wounded. Loyd Lindsay could reflect with pride upon a successful example of independent and responsive voluntary aid. This did not, however, prevent John Furley renewing his critique of Loyd Lindsay's methods in the pages of The Nineteenth Century (Furley, 1885). Furley's consistent advocacy of greater regulation was rewarded in 1899 by the first of a number of re-organisations: the creation of the Central British Red Cross Committee [CBRCC], comprising members of the NAS, the St John Ambulance and the Princess Christian Nursing Reserve. It would soon face its first challenge, once again in Africa.

The South African War of 1899-1902 was to stretch British military and medical resources in unexpected ways. The effects of siege warfare, of the difficult transportation of food and medicines on single-track railways, and of the large numbers of sick requiring prolonged nursing, placed great stress upon hospital orderlies and medical stores, and forced the militarymedical authorities to rely upon volunteers of varying proficiency. Hopes that the CBRCC would be recognised as a central co-ordinating agency were soon dashed. Furley vented his frustration at "lady amateurs" and their vanity projects. ${ }^{48}$ Irritation peaked at the spectacle of the Netherlands Red Cross aiding the armies of the Boer Republic and flying the Dutch flag alongside the Red Cross flag. ${ }^{49}$ This was enough for Kitchener to order their immediate capture and detainment. In light of these troubles, the military reformists who congregated at meetings of the Order of St John proposed two significant re-organisations: the establishment of a new British Red Cross Society under War Office direction, and a re-negotiation of the 1864 Geneva Convention. With Robert Loyd Lindsay's death in 1901, the old voluntary spirit of the NAS had to rely for its defence on the trenchant advocacy of his wife Lady Wantage, a stalwart of its Ladies Committee, and of his nephew, Archie Loyd. But this was to be Sir John Furley's moment..$^{50}$ Working alongside two fellow Knights of the Order, Sir Alfred Koegh, the director-general of the Army Medical Service, and Lord Knutsford, Loyd Lindsay's replacement as Chair of the Red Cross Committee, Furley was commissioned to re- 
port on a re-organisation of voluntary aid in readiness for war. He recommended a new central headquarters for the training, examining and registering of civilian first-aiders, with branches throughout Britain and the empire. Despite objections from leading members of the NAS, who justifiably felt such a scheme jeopardised their independence, a merger of the Central British Red Cross Committee and a reluctant NAS was affected by royal command in July 1905 and the new British Red Cross Society (BRCS) was inaugurated. The BRCS was born on a war footing. It was responsible for creating Voluntary Aid Detachments, to be attached to the Territorial Force at county level and prepared to oversee the transportation of wounded from field ambulance to base hospital in the event of an anticipated German invasion. The British Army now had a co-ordinated system of on-demand voluntary aid for the rapid transport and treatment of the wounded. Nevertheless, if the uncongenial sight of the Dutch Ambulance's open partisanship in South Africa was not to be repeated, then the status of national societies in a future war required clarification. The need now was to ensure that international law accorded with British arrangements.

Since the debacle of the South African War, voluntary medical organisations had been subject to official scrutiny. Not only had the Dutch ambulance staff contravened the neutrality of the Red Cross flag, but the British army was, for the most part, uninformed of the purpose -or even existence- of the CBRCC. In addition, and of particular annoyance to those seeking the supersession of the NAS, the ICRC had continued to recognise the NAS as the official Red Cross organisation in Britain, and it was to the NAS that it sent its communications rather than the CBRCC. ${ }^{51}$ The job of proposing a revision of the 1864 Geneva Convention -and of bringing the ICRC to order-was given to Major-General Sir John Ardagh, a distinguished expert in military intelligence at the War Office. Ardagh sat on the executive of the NAS, and, from 1905, was a member of the new BRCS Council. ${ }^{52}$ In a legal note to the Foreign Office he had exonerated Kitchener's order to haul down the national flag from the Dutch Red Cross Ambulance in the South African War: "In that minute he put forward very clearly the position of voluntary ambulances and pointed out that they had no rights whatever under the Geneva Convention of 1864, except as an act of grace." ${ }^{53}$ Ardagh undertook the review of the Geneva Convention in the company of Surgeon-Major W. G. Macpherson RAMC. Like Ardagh, Macpherson was a proponent of greater regulation on the model of the exemplary medical arrangements of the Japanese Red Cross in the Russo-Japanese War of 1904-1905. They were joined by distinguished professor of academic law Sir Thomas Erskine Holland (author of Laws and Customs of War on Land, which was issued to the British forces in 1904) and by the ever-enterprising Sir John Furley, who had written to offer his services. ${ }^{54}$

Macpherson had been the British government's representative at the Seventh International Conference of Red Cross Societies in 1902. In his private report, he was dismissive of the ICRC, who were, "under nobody's orders, and are not in any way obliged to render an account of their actions." With the activities of foreign ambulances in South Africa still fresh in his mind, he warned that to separate Red Cross societies from the regular army medical services would,

give the Societies that are less under State control, a power of pushing their claims as neutrals in the cause of humanity ... and it would give the International Committee of Geneva a power of interference in the international questions of the Laws and Customs of war, for which it has not special qualification.

"What then becomes of the international Committee?" he asked. His answer was to cut it adrift: "In my opinion they perform no function which is of real importance except in the organization of Peace Conferences and in maintaining a high ideal among those Societies which have not been well organized under State or War Office control." ${ }^{\prime 5}$

When, some years later, Ardagh and his committee reviewed the text of the revised 1906 Geneva Convention, they could reflect with some satisfaction that, "the articles ... in the main agreed with those contained in the British project" (the Projet de Convention Revisée was an advance draft sent by the plenipotentiaries). The ambiguous status of voluntary medical workers was now resolved: official agencies, staffed by voluntary personnel, "must be duly recognised and authorised by their governments ... [and] accorded the same privileges as that of the regular medical service." ${ }^{56}$ By the First World War, the interests of the new British Red Cross Society openly converged with those of an expanded, modernised and "civilianised" military. But it was less straightforwardly the case pace John Hutchinson that the original purpose and independence of the voluntary aid movement had been subverted by its gradual co-option by the War Office, than that a group of reform-minded individuals had successfully advocated for changes in the military's medical arrangements through their opportune experimentation and surveillance as aid workers in foreign conflict. If the standing of the ICRC was challenged by the assertiveness of the national societies, then a more direct threat to its existence was posed by the creation of the American-backed League of Red Cross Societies 1919 (Hutchinson, 1995). And yet, far from wilting, in the immediate post-war period, the ICRC turned to account those "high ideals" which Macpherson had viewed as so insipid, and its elitist, narrow composition (that "irresponsible Committee of Swiss gentle- 
men"), to successfully re-affirm its singular purpose and shore up its authority (Palmieri, 2012, pp. 8-9).

\section{CONCLUSION}

A review of the origins of battlefield philanthropy in Britain suggests the extent to which the history of the Red Cross movement cannot be told without reference to people such as Sir John Furley: adventurer, innovator, humanitarian entrepreneur and humanitarian profiteer. Furley was committed to the efficient treatment of the wounded in war, as early as 1869 recognising the need for "flying hospitals" in place of stationary institutions. He was equally committed to building up the legend of the Order of St John, and his own reputation. Proud of his neutral credentials (derived as much from English chivalry as the protocols of Geneva), he was nevertheless happy to associate himself with individuals at the Order of St John who were outspoken about the need to target aid to Christians in the East. In tracing the history of those claiming to be "doing good" we need to take account of such intricate blends of motivation and ideals. This makes the history of humanitarianism, and of the Red Cross movement, more complex than generally told. The first point to note is that the preservation of life cannot be separated from organisational preservation, or individual ambition. The second is to emphasise that the ICRC was not instrumental in the development of aid work as a field of endeavour. For the ethos of a relief worker such as Furley was not imparted by the ICRC, but was worked out in practice, was contingent, and incorporated shifting meanings of neutrality -was much closer, in other words, to the idea of "humanitarian diplomacy" elaborated by Régnier. In Spain, for example, Furley had employed an arms smuggler as his servant and guide, but one who knew the terrain and could further his quest (Furley, 1905, pp. 301-302). Finally, it has become evident that the preoccupation with the independence of the "NGO" from the state is a modern one: the politics of relief in the nineteenth and early-twentieth centuries were inseparable from the shifting politics of state.

\section{NOTES}

1 See the contributions to anniversary projects in the International Review on the ICRC's website http://www.icrc.org/eng/ resources/international-review/index.jsp. The ICRC was known until the 1880 s as the Comité International, however it is referred to here throughout as the ICRC for ease of reference.

2 "Geneva Convention 1906, The Procedure of the Conference", Ardagh Papers, The National Archives [TNA], London, PRO. 30/40/3.

3 For insightful discussions of the history and politics of the ICRC, but ones which pay little attention to humanitarian practices on the ground, see Hutchinson, 1996, and Forsythe, 2005. See also the review of John F. Hutchinson's Champions of Charity, by S. P. Mackenzie in The Journal of Modern History, Vol. 70, No. 2, June 1998, p. 448.

4 For "affective relationships" see Skinner and Lester, 2012, p. 732.

5 This point is elaborated by Bronwen Everill in her review of Michael Barnett's Empire of Humanity for the Institute of Historical Research http://www.history.ac.uk/reviews/review/1141.

6 Stéphanie Prévost, review of Davide Rodogno's Against Massacre, in Graat, http://www.graat.fr/review_rodogno.htm.

7 Capt. Burgess, "Help for the Sick and Wounded", The Times, 16.7.1870.

8 Lord Overstone to G. W. Norman, 5.8.1870, O’Brien, 1971, vol. III, p. 1202.

9 Overstone to Lord Granville, 20.1.1871, O’Brien, 1971, vol. III, p. 1205.

10 Capt. Burgess, "Help for the Sick and Wounded", The Times, 16.7.1870.

11 Capt. Burgess, Letter to the editor, The Times, 19.7.1870

12 Furley to Longmore, 4.6.1869, Longmore Papers, Wellcome Library, London, RAMC 1139/L/44/1b; The Times, 29.7.1870.

13 The Times, 29.7.1870.

14 See the correspondence between Longmore, Furley, Burgess and Henri Dunant of the ICRC in the Thomas Longmore Papers at the Wellcome Library, recording, for example, Dunant's pleasure at learning Britain had accorded to the Geneva Convention (Dunant to Longmore, 11.1.1865, RAMC 1139/ LP 23/2); on the topic of the creation of an ambulance service in times of war and peace, see the letter from Henry Brackenbury to John Furley of 15.6.1870 (Sir John Furley Papers, British Red Cross Society Archives, London, 0038A/1/3)

15 Nightingale quoted in Hutchinson, 1996, p. 350

16 Florence Nightingale to Sir Thomas Longmore, 14.7.1867, Longmore Papers, RAMC 1139 Box 251, 93/1-118.

17 See their correspondence in the Nightingale Papers, British Library, Department of Archives and Manuscripts, Vol. XXXV, ff.161-214.

18 Sir Thomas Longmore to Major General Sir E. Lugard, UnderSecretary of State for War, 15.11.1864, Longmore Papers, Wellcome Library, RAMC, LP/22/3.

19 Burgess to Longmore, 15.11.1865, Longmore Papers, RAMC 1139 LP 39/1; Longmore, 1866, p. 15. 
20 In 1888 Queen Victoria granted the Order a Royal Charter, making it a British Royal Order of Chivalry, thereby bypassing their rather tenuous connections with the medieval Knights and their ambivalent relationship with the Catholic Order of St John on the Continent. They were keen to establish an amenable history and rules of precedent and investiture and to create appropriately venerable costumes and insignia. For example see, The English or Sixth Langue of the Order of the Hospital of St John of Jerusalem, A brief sketch of its history and present position, printed by Charles Cull \& Son, London, 1879, bound into the Annual Reports for 1858-1879, London, St John Ambulance Museum and Archive.

21 Furley to Longmore 14.12.1869, Longmore Papers, RAMC $1139 / 1 / 44 / 5$.

22 Rundle, n.d., p. 34.

23 F. Creswell Hewett, Recollections of Sedan, printed by Fowler \& Co, Halifax, N.S., 1877, p. 5.

24 For details of the NAS's work see, Report of the Operations of the British National Society for Aid to the Sick and Wounded in War During the Franco-Prussian War, 1870-71, Harrison \& Sons, London, 1871; Gill, 2013, Chapter 2.

25 Letter quoted in Lindsay, 1907, p. 180.

26 NAS, Report, p. 63.

27 Nightingale to Harry Verney, 7.8.1870, The Letters of Florence Nightingale, Wellcome Library, MS 9004/5.

28 Nightingale to Harry Verney, 25.7.1870, The Letters of Florence Nightingale, Wellcome Library, MS 9004/5.

29 Nightingale to Harry Verney, 3.8.1870, The Letters of Florence Nightingale, Wellcome Library, MS 9004/5.

30 Lees also had links with the Order of St John, for whom she worked on a successful scheme of home nursing for the poor. Summers, 2000, p. 120.

31 NAS, Questions on the Operations, 1871. p 15.

32 Nightingale herself declined repeated requests to join the Order. Sir Edmund Lechmere to Nightingale, Nightingale Papers, British Library, Vol. LXVI, ff. 212, 224.

33 NAS, Questions on the Operations, 1871, p. 75.

34 Overstone to Norman, 11.9.1870, O’Brien, 1971, vol. III, p. 1203.

35 Using the National Archives' online Currency Converter $£ 297,000$ in 1870 would now have a spending worth of $£ 13,572,900$.

36 NAS, Report, p. 152.

37 Brackenbury, "Aid to the Injured. Proceedings of a public meeting of the Knights of St John of Jerusalem", A. W. and J. P. Jackson, Woolwich, 1878, Longmore Papers, RAMC 1139 LP 28/1.

38 This extended to considerable self-promotion: in 1872 Furley wrote to Lord Russell at the Foreign Office to request a nomination to the German government for an honour in recognition of his services in the Franco-Prussian War. (Brackenbury, Furley observed, had been honoured, "but I had proceeded him as pioneer"). Furley to Lord Russell, 22.11.1872, TNA, FO 83/2165.

39 A central St John Ambulance Department was in operation by 1874; the country-wide St John Ambulance Association was founded in 1878. Order of St John, 1874, p. 8; Furley, 1883.

40 NAS, Report of the Operations, 1877, p. 10.

41 Sandwith to Freeman, 16.9.1876, Freeman Papers, The John Rylands Library, FA1/2/184.

42 Loyd Lindsay to Disraeli, 11.11.1876, Disraeli Papers, Bodleian Library, Oxford University, B/XVI/C/146.

43 For Furley's relief work during the Carlist War see Arrizabalaga et al. (2013), pp. 350-357.

44 Anderson, 1986, p. 10; Order of St John, 1877, p. 10

45 The Times, 29.9.1876; Strangford's hope for Bulgarian independence was echoed by her fellow Order of St John associate Emma Pearson: "To all thinking persons who really know Servia and the Serbs, it is clear her best hope lies in independence." Pearson \& MacLaughlin, 1877, p. 15. Nevertheless Strangford's sympathies lay with the Disraelian policy of regional stabilisation and non-intervention rather than Gladstone's advocacy of British military involvement on behalf of the region's Christians. See her letter to Disraeli, 25.6.1876, Disraeli Papers, Bodleian Library, B/XVI/B/113.

46 Elizabeth Baigent, entry for Smythe [née Beaufort], Emily Anne, Viscountess Strangford, Dictionary of National Biography Online, www.oxforddnb.com.

47 Henry Brackenbury, "Philanthropy in War", Blackwood's Magazine, Feb 1877, p. 152.

48 Furley to Loyd Lindsay, 29.10.1900, quoted in Hutchinson, 1996,p. 243.

49 On this episode, see also Leo van Bergen's article in this dossier.

50 Furley had been knighted for his services to the wounded in war in 1899.

51 Macpherson complained that "The International Committee of Geneva ... have constituted themselves an authority in whom rests the decision as to what is and what is not a Central Red Cross Committee for other nations." Report on the Seventh International Conference of Red Cross Societies, 1902, TNA, PRO $30 / 40 / 20$.

52 Ardagh served for the NAS in his official capacity during the Sudan Campaign of 1884. His wife and biographer credits Ardagh with the suggestion of inviting the Order of St John, NAS and Princess Christian Army Reserve to the War Office to form the Central British Red Cross Committee in 1899. Harris, 1909, p.399. Lord Knutsford, Chair of the CBRCC urged Ardagh to promote the CBRCC as a peacetime training bureau, and urged the dissolution of the "rival" NAS (and the earmarking of the NAS's substantial funds for the new Central organisation for spending in times of war). Knutsford to Ardagh, n.d., TNA, PRO/30/40/20 
53 Harris, 1909 , p. 399. The British were not immune from the criticism that they had themselves contravened the spirit of the Geneva Convention in South Africa. At the Seventh International Conference of Red Cross Societies, Macpherson, the British delegate, noted accusations of "'undeniable violation of which the English were culpable in South Africa in 1899' in capturing and looting an ambulance of the Orange Free State". Macpherson, Report on the Seventh International Conference of Red Cross Societies, 1902, TNA, PRO 30/40/20.
54 Guy Fleetwood Wilson (War Office) to the Viscount Cranborne, Under-Secretary of State at the Foreign Office, 3.4.1903, TNA, FO 83/2165.

55 Macpherson, Report on the Seventh International Conference of Red Cross Societies, 1902, TNA, PRO 30/40/20.

56 Ardagh, "Geneva Convention 1906, The Procedure of the Conference", Ardagh Papers, TNA, PRO. 30/40/3.

\section{BIBLIOGRAPHY}

Arrizabalaga, Jon; Larraz-Andía, Pablo; Sánchez-Martínez, Guillermo (2013), "Between Medical Innovation and War Propaganda: The Irache Hospital during the Second Carlist War, 1873-1876", in Christopher Bonfield, Jonathan Reinarz and Teresa Huguet-Termes, Hospitals and Communities, 1100-1960, Oxford, Peter Lang, pp. 327-362.

Anderson, Dorothy (1986), The Balkan Volunteers, London, Hutchinson $\&$ Co.

Barnett, Michael (2011), Empire of Humanity. A History of Humanitarianism, Ithaca, NY, Cornell University Press.

British National Society for Aid to the Sick and Wounded in War (1871) Questions on the Operations of the British National Aid Society for Aid to the Sick and Wounded in War, and Replies Thereto, by Various Members of the Society's Staff and Others: Being the Result of Their Experiences in the Franco-German War, 1870-71, London, Harrison and Sons.

British National Society for Aid to the Sick and Wounded in War (1871) Report of the Operations of the British National Society for Aid to the Sick and Wounded in War During the Franco-Prussian War, 1870-71, London, Harrison \& Sons.

British National Society for Aid to the Sick and Wounded in War (1877), Report of the Operations of the British National Society for Aid to the Sick and Wounded in War During the Servian War Against Turkey, 1876, London, J.M Johnson and Sons.

Forsythe, David P. (2005), The Humanitarians: The International Committee of the Red Cross, Cambridge, Cambridge University Press.

Furley, John (1883), On the Carriage of Sick and Injured Persons, $A$ paper read at the meeting of the Social Science Congress, Huddersfield, 1883, London, Spottiswoode and Co.

Furley, John (1885), "The Red Cross", Nineteenth Century, 18 (106), pp. $879-892$.

Furley, John (1905), In Peace and War. Autobiographical Sketches, London, Smith, Elder \& Co.

Gill, Rebecca (2013), Calculating Compassion: Humanity and Relief in War, Britain 1870-1914, Manchester, Manchester University Press.
Harris, Susan (1909), The Life of Major-General Sir John Ardagh by his wife Susan Countess of Malmesbury, London, John Murray.

Hutchinson, John F. (1995), "'Custodians of the sacred fire': the ICRC and the postwar reorganisation of the International Red Cross", in Paul Weindling (ed.), International Health Organisations and Movements, 1918-1936, Cambridge, Cambridge University Press, pp. 17-35

Hutchinson, John F. (1996), Champions of Charity: War and the Rise of the Red Cross, Boulder, Colo., Westview Press.

Lechmere, Sir Edmund (1883), A Visit to the British Hospice and Ophthalmic Dispensary at Jerusalem, A Paper Read before the General Assembly of the Knights of the St John of Jerusalem, London, Harrison and Sons.

Lindsay, Harriet Loyd [Lady Wantage] (1907), Lord Wantage, V.C., K.C.B. A Memoir by His Wife, London, Smith, Elder \& Co.

Longmore, Thomas (1866), On the Geneva Convention of August the $22^{\text {nd }} 1864$, A Lecture Delivered at the Royal United Service Institution, London, Harrison and Sons.

MacCormac, William (1871), Notes and Recollections of an Ambulance Surgeon. Being an account of work done under the Red Cross during the Campaign of 1870 , London, J \& A Churchill.

Moore, Sandford (1872), Notes with a Prussian Sanitäts Detachment in the Loire Campaign, 1870, London, Pardon and Son.

O'Brien, D. P. (ed.) (1971), The Correspondence of Lord Overstone, Cambridge, Cambridge University Press, 3 vols.

Order of St John (1874), Report of the Chapter, London, Harrison and Sons.

Order of St John (1877), Report of the Chapter, London, Harrison and Sons.

Order of St John (1878), Report of the Chapter, London, Harrison and Sons.

Order of St John (1879), The English or Sixth Langue of the Order of the Hospital of St John of Jerusalem, A brief sketch of its history and present position London, Charles Cull \& Son. 
Palmieri, Daniel (2012), "An institution standing the test of time? A review of 150 years of the history of the International Committee of the Red Cross", International Review of the Red Cross, 94 (888), pp. 1-26.

Pearson, Emma; MacLaughlin, Louisa (1877), Service in Servia under the Red Cross, London, Tinsley Brothers.

Régnier, Philippe (2011), "The emerging concept of humanitarian diplomacy: identification of a community of practice and prospects for international recognition", International Review of the Red Cross, 93 (884), pp. 1211-1237.

Rodogno, Davide (2011), Against Massacre: Humanitarian Intervention in the Ottoman Empire 1815-1914, Princeton \& Oxford, Princeton University Press.

Rundle, Henry, FRCS (n.d.), With the Red Cross in the Franco-German War a.d. 1870-1, London, Werner Laurie.

Sandwith, Humphry [Edward Henry Stanley Derby, Earl of Sandwith] (n.d. [1876]), England's position with regard to Turkey and the Bulgarian Atrocities, Liverpool, D. Marples \& Co.
Skinner, Rob; Lester, Alan (2012), "Humanitarianism and Empire: New Research Agendas", Journal of Imperial and Commonwealth History, 40 (5), pp. 729-747.

St John Ambulance Association (1889), Report of the First and Second "Crusades" in the Northern Counties of Durham and Northumberland, London, Charles Cull \& Son.

St John Ambulance Association (1895), Annual Report, London, Charles Cull \& Son.

Summers, Anne (2000), Angels and Citizens: British Women as Military Nurses, 1854-1914, Newbury, Threshold Press.

Trim, D. J. B.; Simms, Brendan (2011), "Towards a history of humanitarian intervention", in D. J. B. Trim and Brendan Simms (eds.), Humanitarian Intervention: A History, Cambridge, Cambridge University Press, pp. 1-24 